Journal of Environmental Sciences (JES)

Faculty of Graduate Studies and Environmental Research, Ain Shams University

Mahmoud, Al-Shimaa.., et al.

\title{
REMOVAL OF MALACHITE GREEN DYE POLLUTANT FROM WATER USING NANO-POROUS STRUCTURE OF MODEFIED NATURAL SOURCE
}

\author{
Al-Shimaa N. Mahmoud ${ }^{(1)}$; Hanan F. Youssef ${ }^{(2)}$ \\ and Taha A. M. Abd El- Razek ${ }^{(3)}$
}

1) HCWW, Holding Company for Water and Wastewater. 2) National Research Centre (NRC), Egypt. 3) Faculty of Graduate Studies and Environmental Research, Ain Shams University

\begin{abstract}
Dyes are pollutants resulted from the textile, paper, and leather industries, are considered sources of environmental contamination. This study is devoted to utilize a low-cost modified local natural source, for removing the Malachite Green cationic dye (MG) from aqueous solution. Zeolite-A (ZA) was prepared in a good Crystallinity via hydrothermal heating from local kaolin at mild conditions. The mineralogical, structural, and chemical properties of both, the precursor rock and ZA that formed were identified via X-ray Diffraction (XRD), scanning electron microscope (SEM), and X-Ray Fluorescence (XRF) techniques. To identify the impact of operational parameters, a series of adsorption studies were performed, such as initial concentration, $\mathrm{pH}$, adsorbent dose, initial dyes concentration, contact time, ionic strength and temperature on the complete dye removal. The thermodynamic parameters $(\Delta \mathrm{H}, \Delta \mathrm{S}$ and $\Delta \mathrm{G})$ of adsorption systems were also determined and evaluated. The resulting degrees of dye removal were $59-86.5 \%$ for initial dye concentration of $10 \mathrm{mg} / \mathrm{L}$ and for ZA loadings of $0.01-1.00 \mathrm{~g}$. It was found that the adsorption of MG on ZA followed a pseudo-second order model, the data proved well fitted to the Langmuir isotherm model and thermodynamic studies showed that the dye adsorption onto ZA is a spontaneous and endothermic. The experimental


Journal of Environmental Sciences (JES)

Faculty of Graduate Studies and Environmental Research, Ain Shams University

Mahmoud, Al-Shimaa.., et al.

results indicated that, the adsorption capacity of ZA for removing the cationic dye MG was $98 \mathrm{mg} / \mathrm{g}$, which is being probably dependent on the geometry of the dye molecules.

Keywords: Zeolite-A, Local source, Malachite green, Adsorption and Thermodynamic parameters.

\section{INTRODUCTION}

Many industries use dyes for coloring their products. The discharge of effluents from such manufacturing processes contains large amount of dyes. Those hazardous materials are, not only damaging the aesthetic nature of receiving water bodies, but also are being toxic to aquatic life (Chakraborty, 2010; Bulut et al., 2008). Malachite green MG is an organic cationic dye, a kind of tri-phenyl methane $\left(\mathrm{C}_{23} \mathrm{H}_{25} \mathrm{~N}_{2} \mathrm{Cl}\right)$. It is widely used in production of the textile, ceramic, leather, food and cell coloring, along with paper formation (Daneshvar et al., 2007; Kaith et al., 2015). MG dye has negative effect on human health, as it can cause harmful effects on liver, gill, kidney, intestine and gonads of aquatic organisms. Contact of malachite green with skin causes irritation with redness and pain. Therefore, the use of malachite green in aquaculture was banned in many countries. It is also considered as carcinogenic and mutagenic source due to the presence of nitrogen in its composition ( $\mathrm{Lu}$ et al., 2015). Therefore, its efficient removal from wastewater is of priority. Generally, the removal of organic dyes from aqueous solutions is highly challenging to decrease this hazardousness (Zhuang et al., 2016; Hosseinzadeh and Abdi, 2017). It has also become 
Journal of Environmental Sciences (JES)

Faculty of Graduate Studies and Environmental Research, Ain Shams University

Mahmoud, Al-Shimaa.., et al.

necessary to have inexpensive and efficient substitute materials which are capable of simultaneously removing organic and inorganic contaminants. Zeolites are aluminosilicate minerals that show crystalline porous identity with exceptional connected pore and channel systems in the molecular size range which designate a relied contribution in catalysis, separation and ion exchange (Bekkum et al., 1991). Zeolite-A is one of the man-made zeolites (also called molecular sieves) that has various and important industrial applications such as desiccation, detergency, adsorption, separation, catalysis, and ion exchanging (Flanigen et al., 1991). Zeolites are usually prepared from Na-silicate and Na-aluminate of pure chemical sources. However, their construction from low-priced resources is of economic importance with good capability of optimizing their synthetic parameters (Roozeboom et al., 1984).

Many attempts were carried out to investigate the ability of both natural (NZ) and synthetic Zeolites (SZ) in eliminating MG from wastewater. It has been reported that NZ (Chinese Zeolite) can effectively adsorb MG in aqueous solution with a higher adsorption capacity of $10 \times 10-5 \mathrm{~mol} / \mathrm{g}$ at 30 $\mathrm{oC}$ and $\mathrm{pH}=6$. In a single component system of this study, the adsorption is found to obey the first-order kinetics, whereas the isotherm is following the Langmuir model (Wang and Ariyanto, 2007). In contrast, using NZ, initial concentration, Clinoptilolite (obtained from Xinyang city in China) in a batch mode testing of the same dye revealed a pseudo second order kinetic and spontaneous endothermic process. The kinetic data were analyzed by 
Journal of Environmental Sciences (JES)

Faculty of Graduate Studies and Environmental Research, Ain Shams University

Mahmoud, Al-Shimaa.., et al.

the Langmuir, Freundlich, Redlich-Peterson, and Koble-Corrigan isothermal models. The better fit for the equilibrium process was KobleCorrigan model with maximum adsorption capacity of $22.17 \mathrm{mg} / \mathrm{g}$ (Han et $a l ., 2010)$. Similarly, different Zeolite nanostructures were also tested to get rid of malachite green dye from aqueous media using a batch method. Obtained data implied that, the adsorption processes fitted well with the pseudo-second-order kinetic model and Langmuir adsorption isotherm. Moreover, the thermodynamic parameters showed spontaneous adsorption process of physisorption and exothermic nature. The maximum adsorption capacity of MG dye was found to reach $29.74 \mathrm{mg} / \mathrm{g}$ (Abd El-Rahman, 2018). In the same context, Zeolite-3A was examined for removing Rhodamine $\mathrm{B}(\mathrm{RhB})$ and Malachite green dyes from water samples. The percentage contribution of each parameter on the removal for $\mathrm{RhB}$ and $\mathrm{MG}$ was determined using ANOVA. It has been found that, the most effective parameters in $\mathrm{RhB}$ and $\mathrm{MG}$ elimination under optimizing conditions were the initial concentration of dye $47.715 \%$ and the $\mathrm{pH} 6.485 \%$, respectively (Rahmani, 2018). Finally, preparing ZA from law-grade Egyptian kaolin indicated high efficiency in many pollutants removal through less energy consuming with law energy consuming through hydrothermal conversion.

\section{MATERIALS AND METHODS}

1) Materials: Local kaolin rock, delivered by Middle East Mining Investments Company (MEMCO) was used as the $\mathrm{Al}$ and $\mathrm{Si}$ source for 510

Vol.(50); Iss.(10); No.(4); Oct.. 2021

ISSN $1110-0826$

Online ISSN 2636-3178 
Journal of Environmental Sciences (JES)

Faculty of Graduate Studies and Environmental Research, Ain Shams University

Mahmoud, Al-Shimaa.., et al.

Zeolite-A synthesis. Malachite green MG dye 99.9\% was purchased from Sigma Aldrich. Potassium phosphate Mono-basic (KH2PO4), Potassium phosphate di-basic (K2HPO4) and Calcium Chloride $(\mathrm{CaCl} 2)$ were purchased from Scharlau. Sodium hydroxide pellets $(\mathrm{NaOH}) 98.9 \%$ and Hydrochloric acid $(\mathrm{HCl}) 37 \%$ were obtained from VWR.

\section{2) Methods}

- Preparation of Zeolite A: Synthesis of Zeolites from crystalline clays such as Kaolin encountered two steps: 1 . Thermal activation of the rock for getting an amorphous material (metakaolinite), and 2. Attacking activated clay with an alkaline solution to maintain the Zeolite phase. The formation of ZA in the current work was done following the method of (Youssef et al., 2008). Typically, Kaolin was heated at $700 \mathrm{oC}$ for $4 \mathrm{~h}$, and then reacted with $3.0 \mathrm{M}$ of $\mathrm{NaOH}$ aqueous solution with a solid/liquid ratio of 1:10. The mixture was charged in a Teflon-lined stainless steel vessel of $100 \mathrm{ml}$ capacity and treated in an electric oven at $80 \mathrm{oC}$ for $4 \mathrm{~h}$. The reaction powder was collected, washed severally with distilled water up to $\mathrm{pH}$ 7-8 and centrifuged for solid- liquid separation. The solid powder was dried at $80 \mathrm{oC}$ for $24 \mathrm{~h}$ and collected in dry, clean plastic containers for phase characterization.

- Instrumentation: A pH meter model (Hach, Sension1) equipped with reference electrode was used to adjust the solutions $\mathrm{pH}$, rotor shaker 15 position model (THERMO, SHKE 2000) equipped with timer was used in batch experiments, centrifuge model (Hermle, Z206A) used for sample Vol.(50); Iss.(10); No.(4); Oct.. 2021 
Journal of Environmental Sciences (JES)

Faculty of Graduate Studies and Environmental Research, Ain Shams University

Mahmoud, Al-Shimaa.., et al.

centrifuging at $6000 \mathrm{rpm}$, electric muffle model (Carbolite, CWF 1200) and residual MG dye in aqueous phase was detected using (Shimadzu UV-VIS) spectrophotometer.

- Adsorption batch experiments: The batch experiments of MG removal by ZA were carried out to study the optimal conditions that governing the efficient elimination of dye from the contaminated water. The studied parameters were: solution $\mathrm{pH}$, adsorbent $\mathrm{ZA}$ dose, initial MG concentration, contact time, ionic strength and temperature. Lab. experiments were performed using a rotatory shaker at a constant shaking rate of $250 \mathrm{rpm}$. The process was done by adding 50ml solution of MG, a desired quantity of $\mathrm{ZA}$ in $250 \mathrm{ml}$ Erlenmeyer flasks. The mixture was agitated in a shaker at the desired temperature and speed for predetermined time intervals. The supernatant was agitated by centrifugation at $6000 \mathrm{rpm}$ for $15 \mathrm{~min}$. The residual concentration in the supernatant was determined and the dye concentration was then detected by UV-VIS Spectrophotometer at a wavelength of $\lambda \sim 620 \mathrm{~nm}$. It is worth mentioning that the percent removal of $\mathrm{MG}$ dye ( $\mathrm{R} \%$ Removal) calculated with the following eq. (1) at different $\mathrm{pH}$ (3-10), ZA dose (0.01-1.0 gm.), concentrations of MG dye (5-2000 mg/L), time (5-300 $\min )$ and concentrations of $\mathrm{CaCl}_{2}(0.01-0.5 \mathrm{M})$.

$$
(\mathrm{R} \%)=\frac{\left(\mathrm{C}_{0}-\mathrm{C}_{\mathrm{e}}\right)}{\mathrm{C}_{\mathrm{o}}} \times 100
$$


Journal of Environmental Sciences (JES)

Faculty of Graduate Studies and Environmental Research, Ain Shams University

Mahmoud, Al-Shimaa.., et al.

Where $: C_{o}(m g / l)$ is the initial conc. of $M G$ dye solution and $C_{e}$ is the residual concentration.

3. Characterization techniques: The X-Ray Diffraction XRD tool was used to identify the mineralogical composition of both; parent kaolin and the prepared ZA powder using BRUKER apparatus, Axs, D8-ADVACE (Germany 2001) by applying $\mathrm{Cu}-\mathrm{K} \alpha$ radiation. The patterns of all synthesized phases were compared to the PDF data. The internal structure of the prepared Zeolite samples was investigated using Scanning Electron Microscope SEM model Philips XL30 attached with EDX unit, with accelerating voltage $30 \mathrm{~K}$.V., magnification $10 \mathrm{x}$ up to $400,000 \mathrm{x}$ and resolution for $\mathrm{W} 3.5 \mathrm{~nm}$. Whereas, the main chemical constituents of the original rock material were detected by the Wavelength Dispersive X-Ray Fluorescence Spectroscopy, Axios advanced, sequential WD XRF spectrometer, PANalytical 2005.

\section{Results and Discussions}

A. Characterization of Zeolite (adsorbent synthesis): The composition of the starting kaolin, from which the Zeolite adsorbent was prepared, is given by the XRF chemical analysis of Table 1. The oxide contents (in weight percentage, $\mathrm{Wt} \%$ ) of the analyzed rock implied an amount of silicon/aluminum ratio of 1.24 . This is suitably close to the unity, which is the same Si/Al ratio in most of the synthetic forms of Zeolite-A (Bougeard et.al, 2000). 
Mahmoud, Al-Shimaa.., et al.

Table(1): Chemical Oxide analysis of kaolin

\begin{tabular}{|c|c|c|c|c|c|c|c|c|c|c|c|c|c|c|c|c|c|}
\hline \multirow[b]{2}{*}{$\frac{\tilde{d}}{\frac{d}{x}}$} & \multicolumn{17}{|c|}{ Elemental analysis (Wt\%) } \\
\hline & 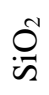 & 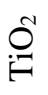 & $\begin{array}{l}\stackrel{0}{1} \\
\underset{Z}{Z}\end{array}$ & $\begin{array}{l}\text { ON } \\
\text { II }\end{array}$ & $\stackrel{0}{\Xi}$ & $\sum_{\substack{0 \\
\sum}}^{0}$ & 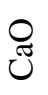 & 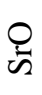 & 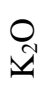 & $\stackrel{\infty}{N}_{2}^{\infty}$ & 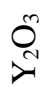 & $\overbrace{0}^{0}$ & $\frac{\wp}{2}$ & 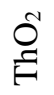 & $\stackrel{\infty}{n}_{2}^{\infty}$ & $\tilde{O}$ & $\begin{array}{l}\bar{\pi} \\
0\end{array}$ \\
\hline : & $\begin{array}{l}\text { त̂ } \\
\text { ñ } \\
\text { ñ }\end{array}$ & ָָ & 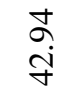 & $\underset{+}{\stackrel{*}{\circ}}$ & $\begin{array}{l}\tilde{O} \\
\dot{0} \\
\dot{v}\end{array}$ & $\stackrel{n}{\circ}$ & $\hat{n}$ & \begin{tabular}{l} 
ָे \\
\hdashline
\end{tabular} & $\stackrel{n}{\circ}$ & $\stackrel{\text { ڤn }}{0}$ & ర্் & $\stackrel{\circ}{\circ}$ & $\stackrel{\Xi}{\stackrel{\Xi}{0}}$ & $\begin{array}{l}\tilde{O} \\
\dot{\theta} \\
\dot{v}\end{array}$ & $\frac{\infty}{n}$ & $\stackrel{n}{\circ}$ & $\begin{array}{l}\dot{\sigma} \\
\text { aे }\end{array}$ \\
\hline
\end{tabular}

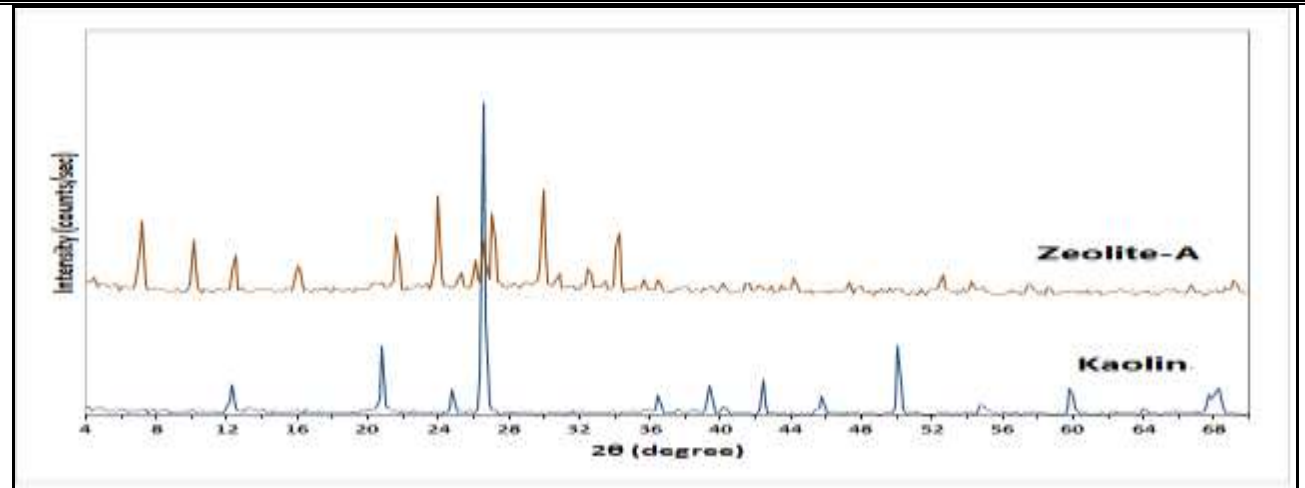

Figure(1): XRD pattern for kaolin and developed Zeolite A.

The XRF analysis for the rock indicated Si/Al contents of nearly 1.24 which is so close to the same ratio of the two elements in the crystalline Zeolite-A (Bougeard et.al, 2000). Figure 1 displays the XRD data for the mineralogy of the starting material (kaolin) and the as-synthesized ZA, developed from attacking calcined kaolin with $3.0 \mathrm{M} \mathrm{NaOH}$ under hydrothermal conditions of $80^{\circ} \mathrm{C}$ for $4 \mathrm{~h}$. The X-ray peaks are so sharp with strong and complete positioning and perfect matching with the reference PDF card \# 73-2340. The absence of remnant peaks of the originally treated rock is indicating a well crystalline product and a complete crystallization process. 


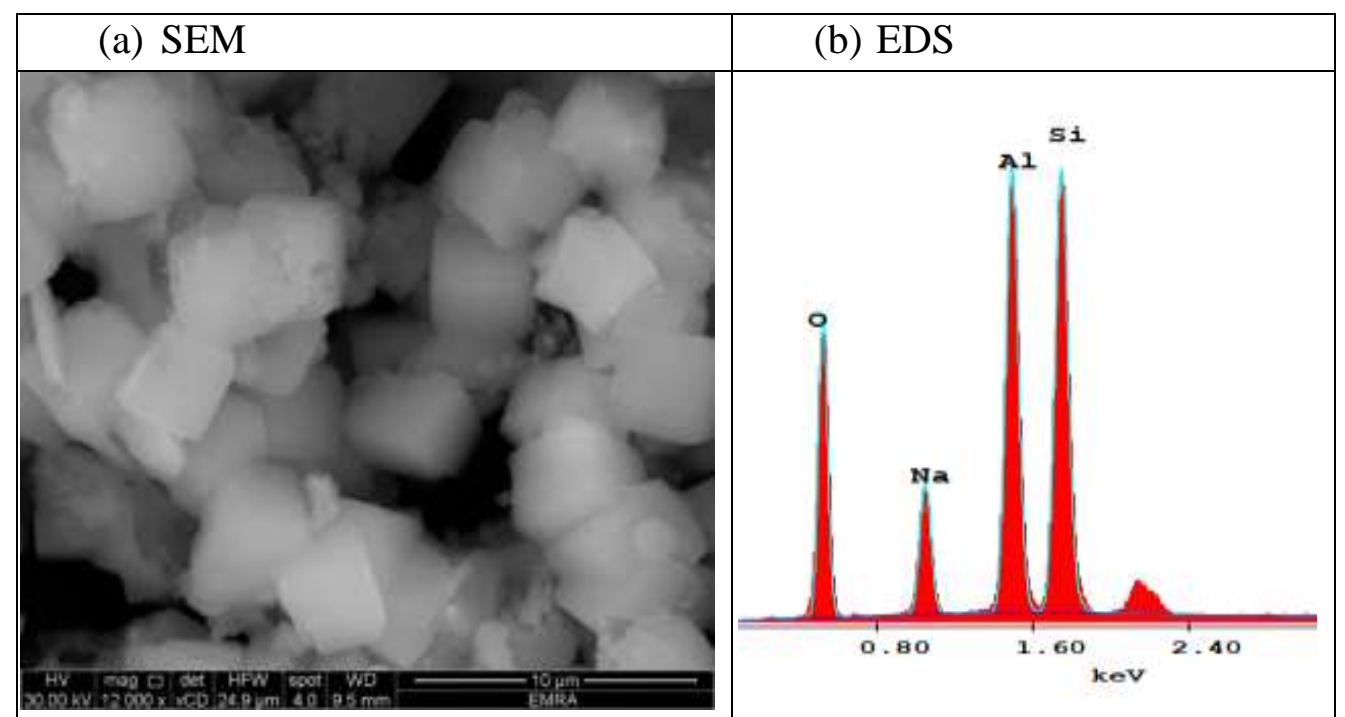

Figure (2): (A) SEM micrographs and (B) EDS chemical microanalysis of the as-prepared ZA powder.

Figure 2 is monitoring the microstructure and the elemental chemical composition of the formed Zeolite-A, obtained from the thermally activated kaolin. Figure 2a is showing the common cubic morphology of ZA, with crystals of unequal sizes in the range of 1-5 microns. Some of the particles are spherical and in a minute sizes, others are very well shaped in a big and small cubic morphology. The different crystallite sizes of the formed Zeolite can be explained by the continuous, successive nucleation and crystallization of the slurry during the whole reaction duration of the conventional heating process. The presence of different crystal generations is explained by the slow temperature rise of the reaction under the 
conventional hydrothermal processing of Zeolites (Bonaccorsi and Proverbio, 2008).

Table(2): EDS elemental analysis of the product

\begin{tabular}{|c|c|c|}
\hline Element & Weight \% & Atomic \% \\
\hline $\mathrm{O} \mathrm{K}$ & 37.84 & 50.48 \\
\hline $\mathrm{Na} \mathrm{K}$ & 9.42 & 8.75 \\
\hline $\mathrm{Al} \mathrm{K}$ & 22.13 & 17.51 \\
\hline $\mathrm{Si} \mathrm{K}$ & 30.61 & 23.27 \\
\hline Total & 100 & 100 \\
\hline
\end{tabular}

On the other hand, Figure $2 \mathrm{~b}$ presents the atomic percentages of $\mathrm{Si}, \mathrm{Al}$, $\mathrm{Na}$, and $\mathrm{O}$ which constitute the main elements that contributed to form ZA framework. It is clear that, the EDS measured value for the Si/Al contents of the monitored Zeolite crystals (average of 5 crystals) was 1.33 which is so close to the previously given Si/Al value (1.24) of XRF analysis. This result is reflecting the siliceous nature of the starting kaolin, see Table 2. It is well known that, the amount of $\mathrm{Al}$ content of a given Zeolite is the determining factor for the cation exchange capacity of such Zeolite type. It is a fact that, the decrease in $\mathrm{Al}$ content resulted in reducing the number of developing negative sites on the porous construction, and in turn, those (negative) charges usually originate from the normal replacement of $\mathrm{Si}$ by $\mathrm{Al}$ during Zeolite formation. Accordingly, the chemical analysis of Zeolites with deficient in aluminum content may show reduced amounts of compensating positive cations, accompanied by some reduction in the whole cation exchange capacity of the micro porous material (Munthali et al., 2014). In 
Journal of Environmental Sciences (JES)

Faculty of Graduate Studies and Environmental Research, Ain Shams University

Mahmoud, Al-Shimaa.., et al.

this work, EDS microanalysis of the obtained ZA (Table $2 \&$ Figure $2 b$ ) is showing an amount of $8.75 \% \mathrm{Na}^{+}$cations/ unite cell of Zeolite-A, which is less than the theoretical amount of the cationic contents of the fully compensated ZA structure per unite cell $\left(12 \mathrm{Na}^{+} \% /\right.$ unite cell) (Munthali et al., 2014).

\section{- Adsorption studies}

A). Determination of zero-point charge (pHZPC): The point of zero charge (pHpzc) means the $\mathrm{pH}$ at which the surface charge of the material equals to zero. To get this value, ZA powder was thermally activated at $105{ }^{\circ} \mathrm{C}$ for $24 \mathrm{~h}$ to eliminate any environmental contaminants that may find their way into the open pores and channels of Zeolite, such as the attached water vapor and $\mathrm{CO}_{2}$. The $\left(\mathrm{pH}_{\mathrm{pzc}}\right)$ of Zeolite was determined by adding $0.1 \mathrm{mg}$ of ZA to $100 \mathrm{ml}$ of water with varying $\mathrm{pH}$ values in the range of 3 to 10 , and adjusted using $0.1 \mathrm{M} \mathrm{HCl}$ or $0.1 \mathrm{M} \mathrm{NaOH}$ on stirring for $24 \mathrm{~h}$. The $\Delta \mathrm{pH}=\left(\mathrm{pH}_{\text {final }}-\mathrm{pH}_{\text {initial }}\right)$ was plotted against the $\mathrm{pH}_{\mathrm{i}}$ as shown in Figure 3, and the point where $\mathrm{pH}_{\mathrm{f}}-\mathrm{pH}_{\mathrm{i}}=0$ was taken as the $\mathrm{pHpzc}$ (Neag et al., 2020). The ( $\mathrm{pH}_{\mathrm{ZPC}}$ ) for $\mathrm{ZA}$ was found at basic $\mathrm{pH} 7.18$, it was proved that, the $\mathrm{pH}$ PzC of Na-X Zeolite was found to be 7.5 (Kiwan et al., 2021). 


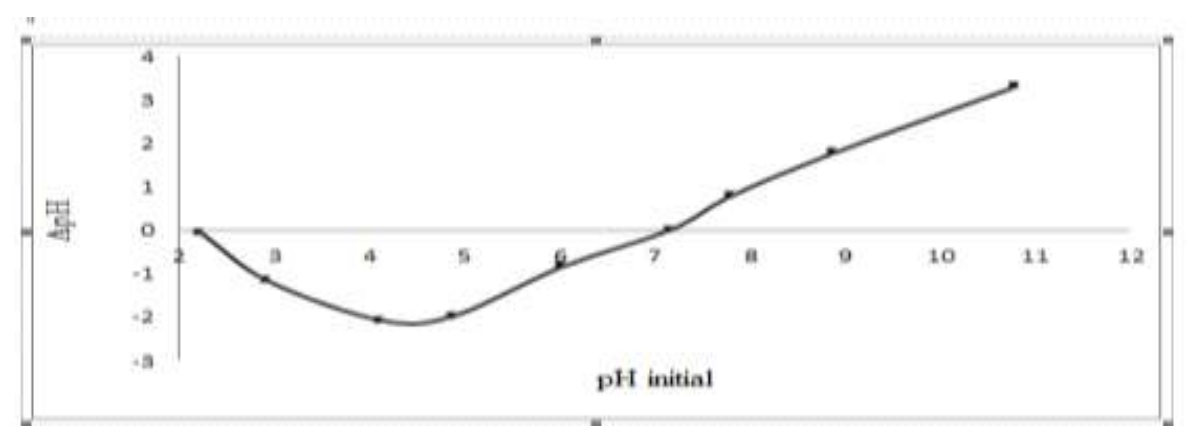

Figure(3): Zero-point-of-charge for Zeolite

B) Effect of $\mathbf{p H}$ : The effect of $\mathrm{pH}$ of the solution on the adsorption capacity of the dye into Zeolite surfaces was conducted to by shaking $0.1 \mathrm{~g}$ of ZA at different $\mathrm{pH}$ values from 3 to $10 \mathrm{in} 50 \mathrm{ml}$ of $\mathrm{MG}$ solution $10 \mathrm{mg} / \mathrm{L}$ in $250 \mathrm{ml}$ glass conical flasks sealed with aluminum foil on a rotary shaker at $250 \mathrm{rpm}$ for $15 \mathrm{~min}$. $\mathrm{pH}$ values were adjusted by phosphate buffer solution and $0.1 \mathrm{M} \mathrm{HCl}$ or $0.1 \mathrm{M} \mathrm{NaOH}$, then centrifuged at $6000 \mathrm{rpm}$ for $15 \mathrm{~min}$. Separate liquid phase followed by samples analyses to determine the optimum $\mathrm{pH}$ value using spectrophotometer.

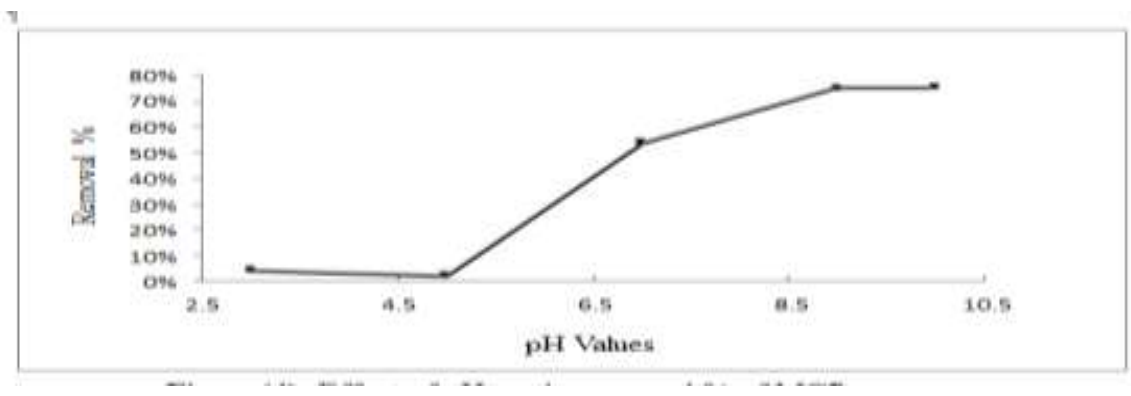

Figure(4): Effect of $\mathrm{pH}$ on the removal \% of $\mathrm{MG}$ 
Journal of Environmental Sciences (JES)

Faculty of Graduate Studies and Environmental Research, Ain Shams University

Mahmoud, Al-Shimaa.., et al.

Figure 4 illustrates the adsorption of MG onto $\mathrm{ZA}$ at various $\mathrm{pH}$ values based on initial MG concentration $10.0 \mathrm{mg} / \mathrm{L}$, adsorbent dose $0.1 \mathrm{~g}$ and contact time $15 \mathrm{~min}$. It was noticed from the curve that, the best adsorptions of MG were obtained in basic $\mathrm{pH}$ values 9 to 10 . The variation in the dye uptake with respect to the initial solution $\mathrm{pH}$ can be explained based on the structure of dye molecule and the point of zero charge (pHzPC) of ZA. For $\mathrm{ZA}$, the point of zero charge is found to be 7.18 and the carboxylic groups of $\mathrm{MG} \mathrm{pKa}=10.3$ were protonated and had high positive charge density at a lower $\mathrm{pH}$ (Garg et al., 2003). At a pH higher than $\mathrm{pHzPC}$, the ZA particle acquires a negative surface charge and favors uptake of cationic dyes due to the increase of the electrostatic force of attraction. At a $\mathrm{pH}$ lower than pHzPC, on additional, the ZA surface acquires a positive charge, and dye molecules gain a positive charge as well. Due to this explanation, there is an electrostatic repulsion between dye molecules and ZA that causes the reduction in dye uptake. It also has been reported that adsorption of MG onto NZ (Natural Zeolite) increases as $\mathrm{pH}$ is enhanced (Wang and Ariyanto, 2007). The best adsorption of MG dye was obtained in basic $\mathrm{pH}$. At low $\mathrm{pH}$ values, due to formation of positive charge on the surface of adsorbent and protonation of dyes little electrostatic interaction occurs between 3A Zeolite and dyes (Rahmani et al.,2018), and this result complies with (Kiwan et al., 2021). 
C): Effect of adsorbent dose: The effect of adsorbent dosage was conducted by adding desired amounts of ZA 0.01, 0.025, 0.05, 0.1, 0.2, 0.3, 0.4, 0.5, 0.7 and $1 \mathrm{~g}$ at the optimum $\mathrm{pH} 9$ and $50 \mathrm{ml}$ of $\mathrm{MG}$ solution concentration $10 \mathrm{mg} / \mathrm{L}$ in distilled water shacked for $15 \mathrm{~min}$ at $250 \mathrm{rpm}$.

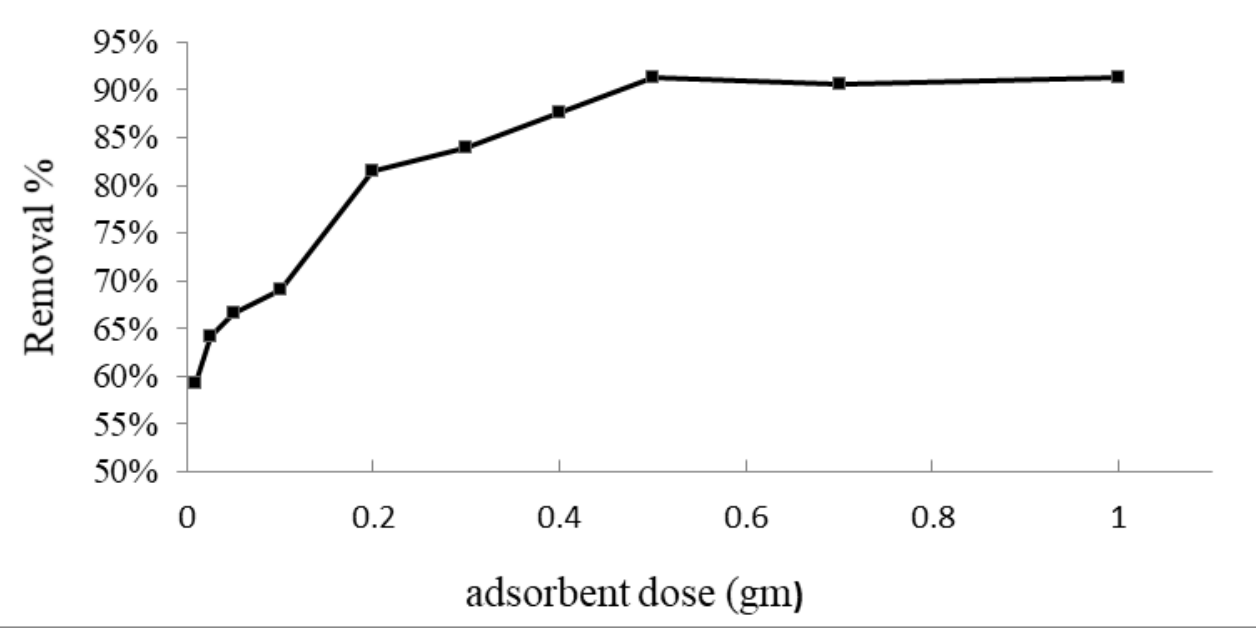

Figure(5): Effect of Adsorbent Dose on the removal \% of MG

Figure 5: shows the adsorption behavior of $\mathrm{MG}$ versus various adsorbent amounts in the range of $0.01-1.0 \mathrm{~g} / 50 \mathrm{ml}$ with initial concentration $10.0 \mathrm{mg} / \mathrm{L}$ and contact time $15 \mathrm{~min}$. It is clear that the percentage of MG removal has been increased with the increase of adsorbent dose. Such a trend is mostly attributed to an enlargement in the adsorbent surface area and the availability of more active adsorption sites. Although the percentage removal of dye is increased with the increasing of adsorbent dose, the equilibrium adsorption capacity $\left(\mathrm{q}_{\mathrm{e}}\right)$ for $\mathrm{MG}$ is 
Journal of Environmental Sciences (JES)

Faculty of Graduate Studies and Environmental Research, Ain Shams University

Mahmoud, Al-Shimaa.., et al.

decreased (as explained equation 2). This might be related to the decrease in the total adsorption surface area available to dye molecules resulting from overlapping or aggregation of adsorption sites. Thus by increasing the adsorbent mass, the amount of dye adsorbed onto unit mass of adsorbent could be reduced. Furthermore, the maximum dye removal $91.35 \%$ for ZA was recorded at $0.5 \mathrm{~g} / 50 \mathrm{ml}$ and the optimal dosage was $0.2 \mathrm{~g} / 50 \mathrm{ml}$ with removal ratio $81.48 \%$ to reduce the economic effect between the two dosages and any further increase in adsorbent dose will not significantly change the adsorption yield. This is due to the binding of almost all dye molecules to adsorbent surface and the establishment of equilibrium between the dye molecules on the adsorbent and in the solution. Han et al. also confirmed this result for using Zeolite to remove MG by microwave irradiation (Han et al., 2010). The amount of adsorbent dose (3A Zeolite) significantly affects the adsorption of MG dye. With increasing of adsorbent dosage, the removal efficiency was increased because of the increase in the available sorption surface sites (Rahmani et al., 2018).

The adsorption capacity of the ZA adsorbent $\mathrm{q}_{\mathrm{e}}(\mathrm{mg} / \mathrm{g})$ can be estimated using following Eq. (2):

$$
\mathrm{q}_{\mathrm{e}}=\frac{\left(\mathbf{C}_{\mathrm{o}}-\mathbf{C}_{\mathrm{e}}\right)}{\mathbf{m}} \times \mathbf{V}
$$

Where, $C_{o}(\mathrm{mg} / \mathrm{l})$ is the initial conc. of MG dye solution, $\mathrm{C}_{\mathrm{e}}$ is the residual concentration of MG, V $(\mathrm{L})$ is the volume of solution and $\mathrm{m}(\mathrm{g})$ is the weight of the ZA. 
D) Effect of MG Dye concentrations: To investigate the effect of MG concentration, experiments were carried out by adding $0.2 \mathrm{~g}$ of $\mathrm{ZA}$ at optimum $\mathrm{pH} 9$ to $50 \mathrm{ml}$ of $\mathrm{MG}$ with different concentrations 5, 10, 15, 20, $30,40,50,60,100,150,200,300,500,600,800,1000$ and $2000 \mathrm{mg} / \mathrm{L}$ using the same previously mentioned conditions.

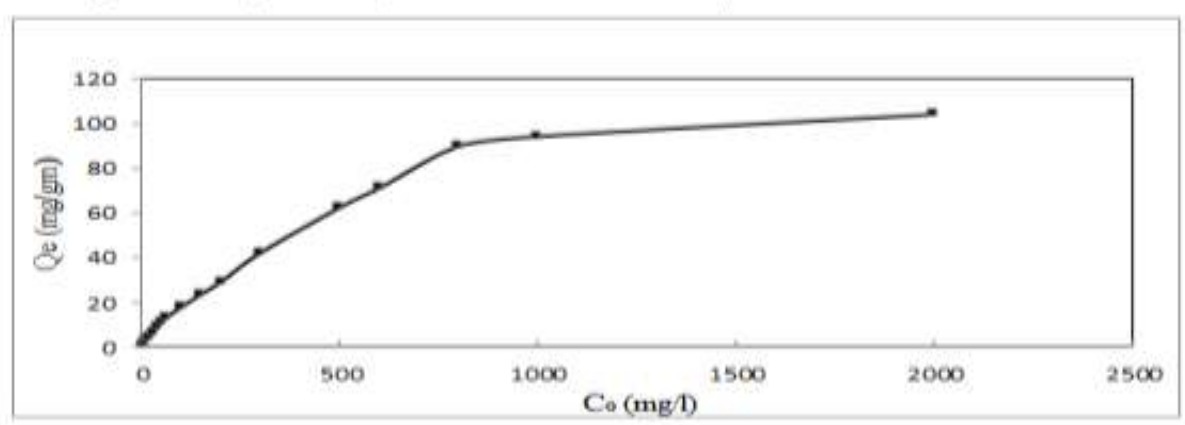

Figure(6): Effect of adsorption capacity of Zeolite-A against initial concentration of MG

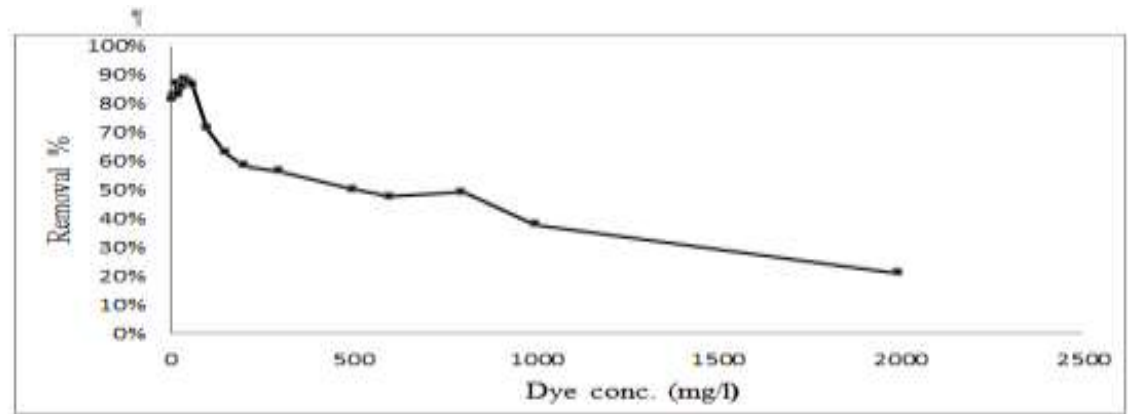

Figure(7): Effect of initial dye (MG) concentration on removal \%

In Figures $6 \& 7$ the effect of different initial dye concentrations adsorption ZA is presented. It's worth mentioning that increasing the initial 
dye concentration reduced the percentage of MG removed. This can clarify that the ZA has a limited number of active sites, which become saturated at a certain concentration. However, the adsorption capacity at equilibrium could increase by growing initial MG dye concentration. This will lead to an increasing in equilibrium sorption until sorbent saturation is achieved with maximum adsorption capacity $\left(\mathrm{q}_{\max }\right) 98 \mathrm{mg} / \mathrm{g}$ for ZA, this result shows an agreement with (Rahmani et al., 2018). The percent removal over the asprepared different types of Zeolite nanostructures increase as the concentration of the malachite green dye decrease (Abdelrahman, 2018).

E) Effect of agitation time: To explain equilibrium time it was conducted by shaking $0.2 \mathrm{~g}$ of $\mathrm{ZA}$ at optimum $\mathrm{pH} 9$ and $\mathrm{MG}$ solutions of $(800 \mathrm{mg} / \mathrm{L})$ in distilled water for different time intervals of $(5,15,30,60,90,120$, 150, 180, 240 and $300 \mathrm{~min}$ ) then centrifuged at $6000 \mathrm{rpm}$ for $15 \mathrm{~min}$.

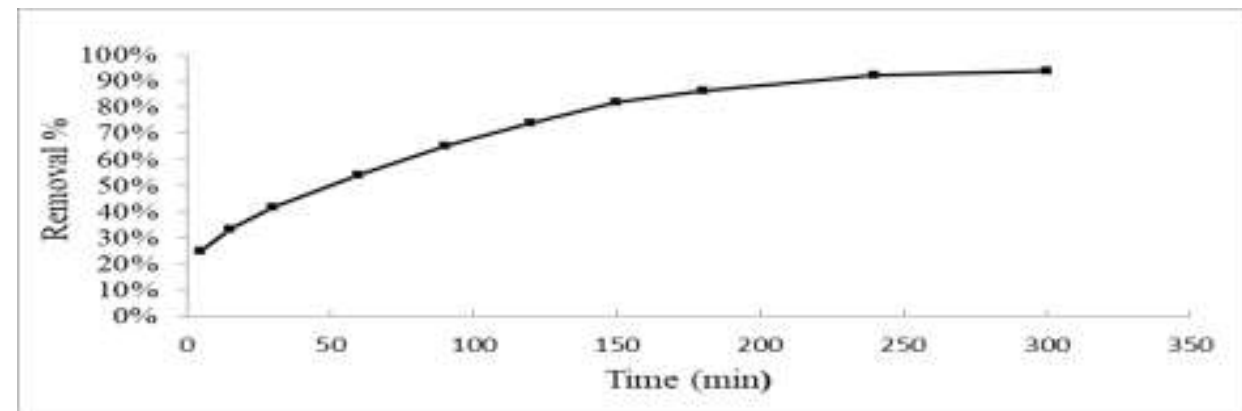

Figure(8): Effect of agitation time on removal \% of MG

In the sorption experiment, the effect of contact time is important, as the data will allow confirmation on the length of agitation time. This will get the adsorption processes between the solid phase (adsorbent) and aqueous 
Journal of Environmental Sciences (JES)

Faculty of Graduate Studies and Environmental Research, Ain Shams University

Mahmoud, Al-Shimaa.., et al.

phases (adsorbates) into a state of balance. Figure 8 summarized the data of the contact time effect of MG removal. The adsorption of MG $800 \mathrm{mg} / \mathrm{L}$ over ZA has presented a similar process in which the adsorption of MG dye has increased with the agitation time raise. The equilibrium has been reached in the adsorption phase after 240min for ZA. The initial rapid adsorption rate could be explained by an increase in the number of active binding sites on the surface of adsorbent. This result shows conformity with (Jain et al., 2015). The removal efficiency increases as the contact time increases (Rahmani et al., 2018).

f) Effect of ionic strength: Adsorption efficiency depends on the electrostatic interactions between the cationic dye molecules and ZA binding sites. $\mathrm{MG}$ solutions were prepared with $\mathrm{CaCl}_{2}$ salt to clarify the effect of ionic strength on adsorption to remove MG, the experiments were carried out at different conc. of $\mathrm{CaCl}_{2}(0.01,0.05,0.1,0.3$, and $0.5 \mathrm{M}$ ) in $50 \mathrm{ml} \mathrm{MG} \mathrm{soln.} 800 \mathrm{mg} / \mathrm{L}, 0.2 \mathrm{gm}$. ZA, pH 9, shaking at 250 rpm for 240min and centrifuged at $6000 \mathrm{rpm}$ for $15 \mathrm{~min}$.

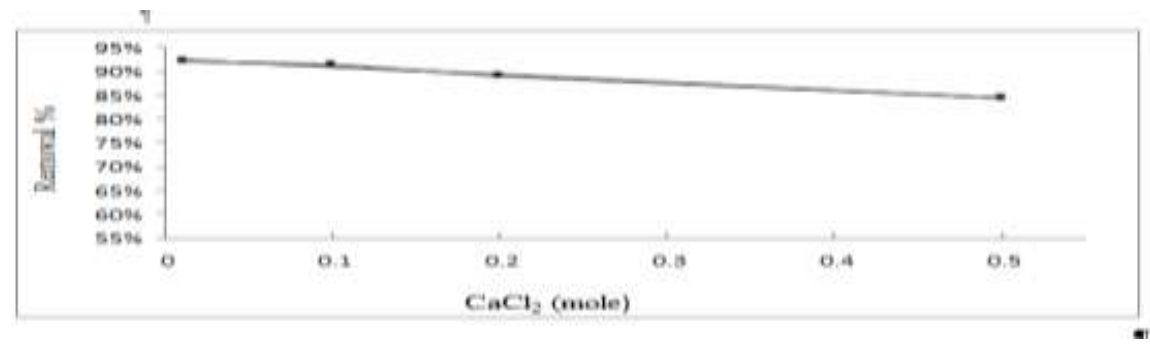

Figure(10): Effect of ions strength on removal\% of MG over Zeolite-A 
The effect of calcium chloride on the adsorption of MG over ZA has been shown in Figure 10. With calcium chloride concentration increase from 0.01 to $0.50 \mathrm{~mol} / \mathrm{L}$, we found that, the adsorption percentage of MG has decreased from 92.2 to $84.5 \%$ this behavior could be attributed due to the competitive effect between dyes cations and ions from the salt $\left(\mathrm{Ca}_{2}+\right)$ for the sites available for the sorption process, this result has conformity with (Mittal et al., 2020).

- Adsorption kinetic: For comprehending more data about the adsorption mechanism, different kinetic models are applied; pseudo-first- or pseudosecond-order reaction (Seen Eq. (3) and Eq. (4))

\section{Pseudo first order:}

$$
\operatorname{Ln}\left(\mathrm{q}_{\mathrm{e}}-\mathrm{q}_{\mathrm{t}}\right)=\ln \mathrm{q}_{\mathrm{e}}-\mathrm{K}_{1} \mathrm{t}
$$

Where, qt is the amount adsorbed at time $\mathrm{t}$, and $\mathrm{k} 1$ is the first-order rate constant (Gupta et al., 2016; Wang et al., 2018; Farghali et al., 2021).

\section{Pseudo second order:}

$$
\frac{t}{q t}=\frac{1}{K_{2} q e^{2}}+\frac{1}{q e} t
$$

Where, $\mathrm{t}$ is the adsorption time, qe and $\mathrm{q},(\mathrm{mg} / \mathrm{g})$ are the adsorbed amount of MG at equilibrium, $\mathrm{k} 2$ is the second-order rate constant (Ho \& McKay 1999; Wu et al., 2009; Yao et al., 2010). 
Journal of Environmental Sciences (JES)

Faculty of Graduate Studies and Environmental Research, Ain Shams University

Mahmoud, Al-Shimaa.., et al.

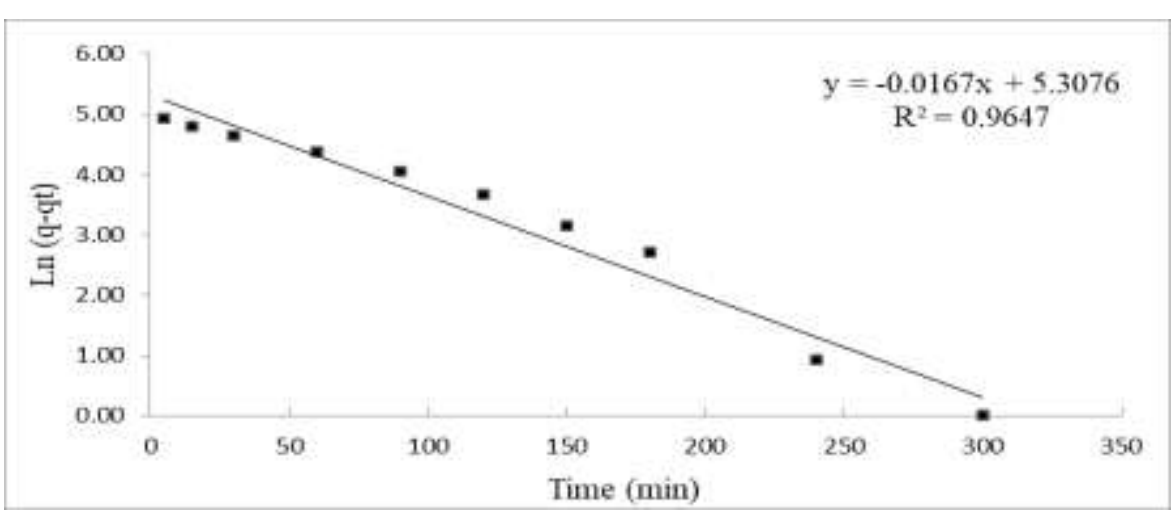

Figure(9.a): Kinetic plots of pseudo First order for the adsorption of MG over ZA

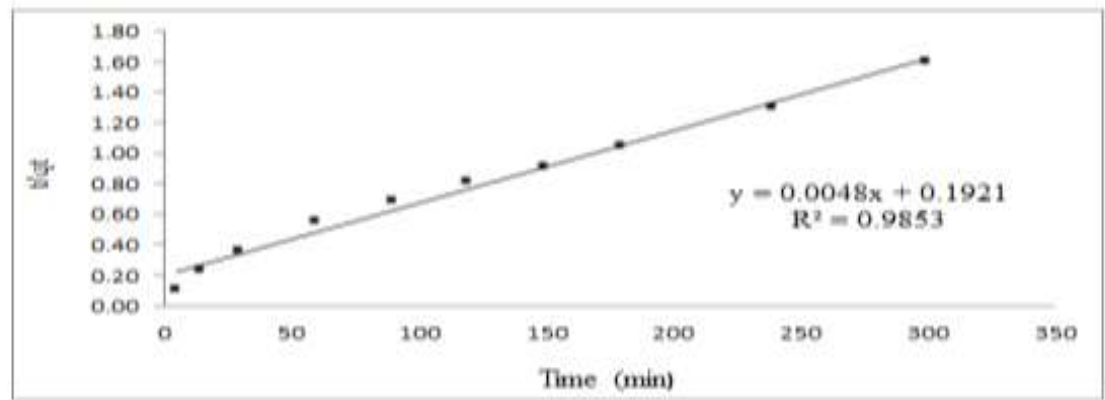

Figure (9.b): Kinetic plots of pseudo second order for the adsorption of MG over ZA

Figure $9(\mathrm{a}, \mathrm{b})$ demonstrates pseudo first-order and pseudo second-order graphics for the adsorption kinetics of studied MG dye. The accordance between the experimental data and the model-predicted values was defined using the correlation coefficients $\left(\mathrm{R}^{2}\right)$. When the values $\mathrm{R}^{2}$ are significantly higher, it means that the model has stated successfully the kinetics of MG adsorption. The data outcomes indicate good accordance with the second- 
order kinetic model with correlation coefficients 0.9853 for ZA. In Table 4, the regression coefficient $\left(\mathrm{R}^{2}\right)$ for second-order model is detected higher than first-order one. This result also has an agreement that adsorption of MG over Zeolite is fitted well with the pseudo-second-order kinetic model (Han et al, 2010; Abdelrahman, 2018). Adsorption kinetics followed the pseudosecond-order type kinetic and intra-particle diffusion played an important role onto adsorption mechanism of malachite green and natural Zeolite (Tanyol, 2017).

Table(3): Kinetics parameters of MG adsorption by ZA

\begin{tabular}{|r|r|r|r}
\hline Adsorbent & Parameters & Pseudo First order & Pseudo Second or \\
\hline \multirow{2}{*}{ ZA } & $\mathrm{R}^{2}$ & 0.9647 & 0.98 \\
\cline { 2 - 4 } & qe calc. & 203048.4 & 20 \\
\cline { 2 - 4 } & qe exp. & & 18 \\
\hline
\end{tabular}

- Effect of Temperature on the Adsorption and Thermodynamics: To explain the effect of temperature, thermodynamic experiment carried out at optimum points of $\mathrm{pH} \mathrm{9,} \mathrm{concentration} \mathrm{of} \mathrm{MG} 800 \mathrm{mg} / \mathrm{L}$, dose of adsorbent $0.2 \mathrm{~g}$ and time $240 \mathrm{~min}$ at 308,318 and $333 \mathrm{~K}$. 
Journal of Environmental Sciences (JES)

Faculty of Graduate Studies and Environmental Research, Ain Shams University

Mahmoud, Al-Shimaa.., et al.

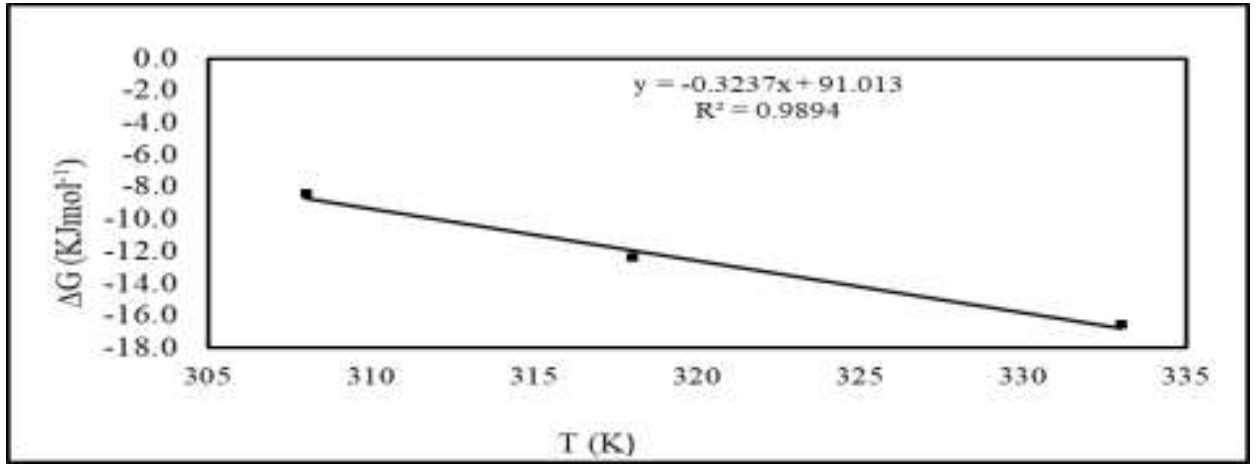

Figure(11): Plots $\Delta \mathrm{G}^{\circ}$ versus $\mathrm{T}$ for adsorption of MG over ZA

The adsorption of MG on ZA was carried out at different temperatures (35, 45 and 60 0C) for the initial concentration of $800 \mathrm{mg} / \mathrm{L}$. The free energy of adsorption $\Delta \mathrm{G}^{\circ}$ was calculated from the following equation:

$$
\Delta \mathbf{G}=-\mathbf{R T} \ln K
$$

Where, $\mathrm{K}$ is the equilibrium constant, $\mathrm{T}$ is the solution temperature and $\mathrm{R}$ is gas constant $8.314 \mathrm{~J}=\mathrm{mol} \mathrm{K}$.

The apparent enthalpy of adsorption $\Delta \mathrm{H}^{\circ}$ and entropy of adsorption $\Delta \mathrm{S}^{\circ}$ were calculated from adsorption data at different temperatures using the Van't Hoff Eq. (5).

$$
\ln \mathrm{K}=\Delta \mathrm{SR}-\left(\frac{1}{T}\right)
$$

Data obtained from the experiments are presented in Figure 11. Temperature is a well-known factor that has a significant impact on any adsorption process. Therefore, batch adsorption experiments were performed at a variety of temperatures, from 308 to $333 \mathrm{~K}$. The findings clearly showed that, adsorption of MG over ZA have risen in parallel with 528 
Journal of Environmental Sciences (JES)

Faculty of Graduate Studies and Environmental Research, Ain Shams University

Mahmoud, Al-Shimaa.., et al.

the rise in temperature. The observed increase in the adsorption capacity with temperature rise shows that, the removal is assisted by a high temperature of MG molecules by ZA. This is because a high temperature could thicken the boundary layer, reducing the dye molecules' tendency to escape from the adsorbent surface and enter the solution process. The $\Delta \mathrm{H}^{\circ}$ and $\Delta \mathrm{S} \circ$ values were determined from the slope and intercept of the plot of $\Delta \mathrm{G}^{\circ}$ versus $\mathrm{T}$. The obtained results as showed in Table 4 that the (negative) values of $\Delta \mathrm{G}^{\circ}$ and positive value of $\Delta \mathrm{H}^{\circ}$ mean that the $\mathrm{MG}$ adsorption process is a spontaneous and endothermic process. The positive value of $\Delta \mathrm{S} \circ$ means the adsorption changes with temp. Increase, this result has an accordance with (Han et al., 2010) who reported that the adsorption of MG and natural Zeolite was spontaneous and endothermic process. The change in free energy for physisorption and chemisorption is recorded between -20 and $0 \mathrm{~kJ} / \mathrm{mol}$, and 80 to $-400 \mathrm{~kJ} / \mathrm{mol}$, respectively (Tehrani-Bagha et al., 2011). In this study, the values rang of $\Delta \mathrm{G}^{\circ}$ for $\mathrm{ZA}$ is obtained equal to (8.39 to $-16.58 \mathrm{~kJ} / \mathrm{mol}$ ) these (negative) values indicate that the physisorption is the dominating mechanism which is also has a conformity with (Abd-elrahman, 2018). 
Table(4): Thermodynamic parameters for MG adsorption on ZA under different temperatures

\begin{tabular}{|c|c|c|c|c|}
\hline \multicolumn{5}{|c|}{$\mathbf{Z A}$} \\
\hline $\mathbf{T}$ & $\mathbf{K a}$ & $\Delta \mathbf{G}^{\circ}$ & Slope $\left(\Delta S^{\circ}\right) \mathrm{KJ} / \mathrm{mol} . \mathrm{k}$ & Intercept $\left(\Delta \mathrm{H}^{\circ}\right) \mathrm{KJ} / \mathrm{mol}$ \\
\hline 308 & 26.50 & -8.39 & \multirow{3}{*}{0.32} & \multirow{3}{*}{91.01} \\
\hline 318 & 109.00 & -12.40 & & \\
\hline 333 & 399.00 & -16.58 & & \\
\hline
\end{tabular}

- Adsorption Equilibrium

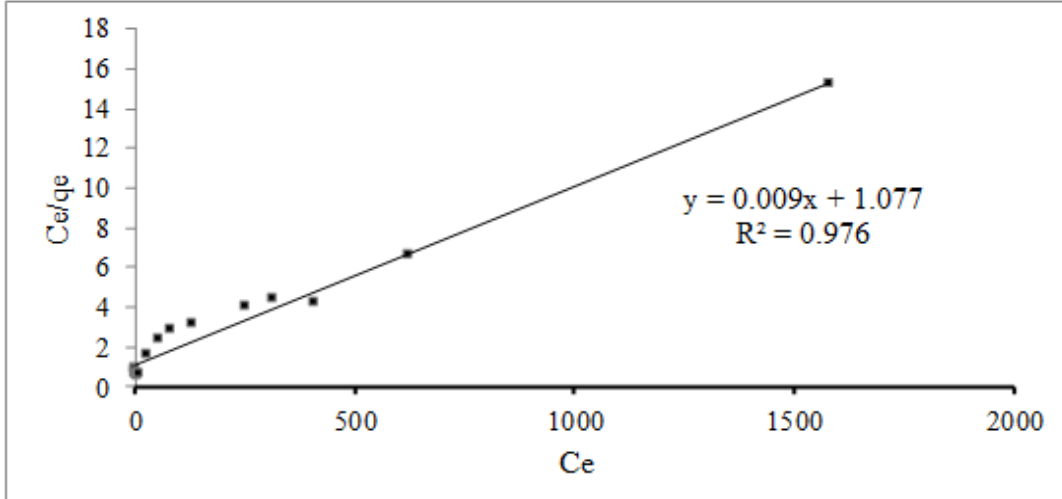

Figure (12.a): Langumuir adsorption isotherm of MG on ZA

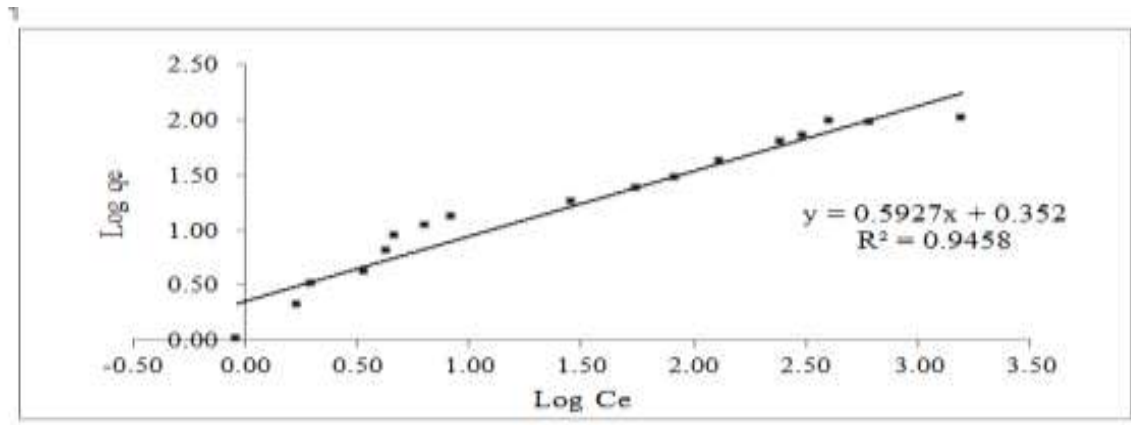

Figure (12.b): Freundlich adsorption isotherm of MG on ZA 
Journal of Environmental Sciences (JES)

Faculty of Graduate Studies and Environmental Research, Ain Shams University

Mahmoud, Al-Shimaa.., et al.

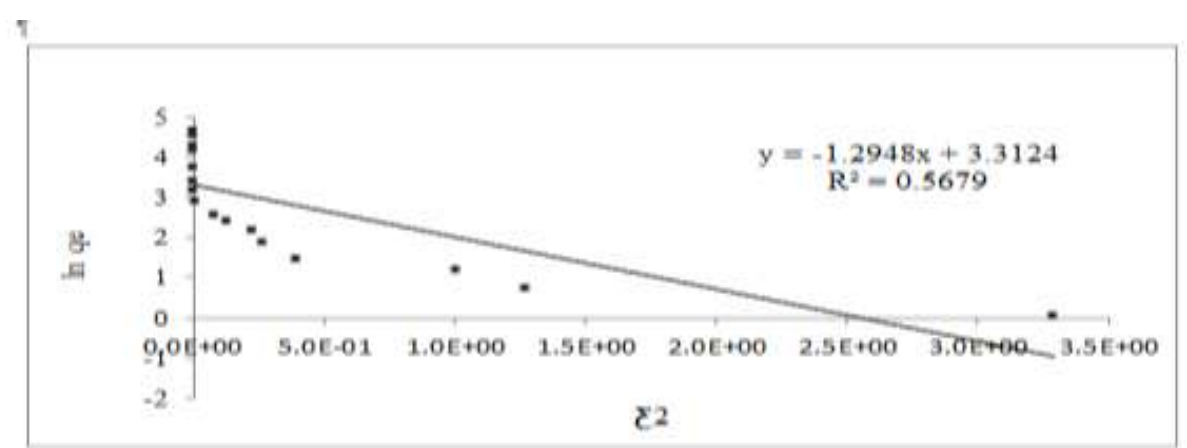

Figure (12.c): (D-R) adsorption isotherm of MG on ZA

An adsorption isotherm is a curve relating the equilibrium of an adsorbate on the surface of an adsorbent, (qe), to the concentration of the adsorbate in the Liquid, (Ce). Langmuir, Freundlich, and DubininRaduskevitch (D-R) isotherm equations were used to analyze the equilibrium data in order to disclose the adsorption behavior of MG to ZA. Linear forms of Langmuir, Freundlich, and D-R isotherm equations are given below as equations. (7), (8), and (9) respectively. Related constants were calculated and given in Table 4.

$$
\begin{aligned}
& \frac{\mathrm{Ce}}{\mathrm{qe}}=\frac{\mathrm{Ce}}{\mathrm{qmax}}+\frac{1}{\mathrm{Kqmax}} \\
& \log =\log \mathrm{K}_{\mathrm{f}}+\mathbf{n} \cdot \log \mathrm{ce} \\
& \ln \mathrm{q}=\ln \mathrm{qm}_{\mathrm{qm}}-\mathrm{K} \dot{\varepsilon}^{2} \mathrm{P}
\end{aligned}
$$

where, qm is the maximum adsorption at monolayer coverage in $\mathrm{mg} / \mathrm{L}$; $\mathrm{K}$ is the adsorption equilibrium constant related to the energy of adsorption in $1 / \mathrm{mg}$; KF and n, Freundlich constants representing the adsorption capacity and intensity respectively; $\mathrm{K}$ is the equilibrium constant related to the Vol.(50); Iss.(10); No.(4); Oct.. 2021 531 ISSN $1110-0826$ Online ISSN 2636-3178 
adsorption energy; $\varepsilon$ p is the Polanyi potential and it was calculated using the following equation:

$$
\dot{\varepsilon}_{\mathrm{p}}=\mathrm{RT} \ln \left(1+\frac{1}{\mathrm{Ce}_{\mathrm{e}}}\right)
$$

Where, $\mathrm{R}$ is the gas constant $(8.13 \mathrm{~J})$ and $\mathrm{T}$ is temperature in kelvin.

$E$ is the mean free energy of adsorption and can be calculated using the following equation:

$$
\mathrm{E}=(-2 \mathrm{~K})-0.5
$$

Table(5): adsorption isotherm parameters of MG on ZA

\begin{tabular}{||c|c|c|}
\hline \multicolumn{3}{|c|}{ ZA } \\
\hline \multicolumn{3}{|c|}{ Langmuir isotherm } \\
\hline \hline $\mathrm{qm}(\mathrm{mg} / \mathrm{g})$ & $\mathrm{K}(\mathrm{l} / \mathrm{mg})$ & $\mathrm{R} 2$ \\
\hline 110.4 & 0.01 & 0.9670 \\
\hline $\mathrm{KF}$ & $\mathrm{N}$ & $\mathrm{R} 2$ \\
\hline 2.26 & 1.69 & 0.9458 \\
\hline $\mathrm{Q}$ & $\mathrm{D}-\mathrm{R}$ isotherm & $\mathrm{R} 2$ \\
\hline 27.28 & $\mathrm{E}(\mathrm{kJ} / \mathrm{mol})$ & 0.5679 \\
\hline
\end{tabular}

In the present study, the Langmuir, Freundlich and DubbinRadushkevich isotherm models were performed. Detailed descriptions about fitted isotherm models on the experimental data are summarized in Table 5 the main objective is to describe the adsorption process of MG on ZA. According to the $\mathrm{R}^{2}$ values in Table 5, Langmuir was selected as the best isotherm model with $\mathrm{R}^{2}=0.967$, with calculated adsorption capacity $\mathrm{Vm}=$ $110.4 \mathrm{mg} / \mathrm{g}$ that derived from Langumuir model are obtained close to the experimental values $q$ max $=98 \mathrm{mg} / \mathrm{g}$ for ZA. It can be worthy concluded 
Journal of Environmental Sciences (JES)

Faculty of Graduate Studies and Environmental Research, Ain Shams University

Mahmoud, Al-Shimaa.., et al.

that langumuir describes monolayer coverage of MG over ZA. The model has also suggested that ZA surface is homogenous and uniform distribution of sites and their energies. As well confirmed by Abdelrahman, who informed that the adsorption of $\mathrm{MG}$ over a synthesized Zeolite nanostructures fitted well with langmuir model (Abdelrahman, 2018), This result is in accordance with those of the study (Ariyanto, 2009; Tanyol, 2017). In order to comprehend the adsorption type, an equilibrium data has been examined by D-R isotherm. Straight lines are created by plotting (ln qe) versus (É2P), which indicates that the adsorption of MG over ZA obeys the D-R isothermal equation in the whole concentration range investigated. Values qm and $\mathrm{K}^{\prime}$ can be calculated from the intercepts and slopes of the plots are shown in Figure 12. Based on $\mathrm{K}$ values, it might be possible to estimate the free energy of adsorption (E), which is described by the free energy change when 1.0 mole of ion is transferred to the surface of the solid from infinity in solution. E value is beneficial for the type of adsorption calculations and if this value is found between 8.0 and $16 \mathrm{KJ} / \mathrm{mol}$, the adsorption type can be explained by ion exchange. The value of $\mathrm{E}$ in this study is found within the energy range of physical adsorption $\mathrm{E}<8.0$ $\mathrm{KJ} / \mathrm{mol}$. As shown in Table 6 the calculated values of $\mathrm{E}$ are smaller than 8.0 $\mathrm{KJ} / \mathrm{mol}=0.62$ for $\mathrm{MG}$, this indicating that adsorption of $\mathrm{MG}$ onto ZA is physical in nature, which has an accordance with (Abdelrahman, 2018). 
Journal of Environmental Sciences (JES)

Faculty of Graduate Studies and Environmental Research, Ain Shams University

Mahmoud, Al-Shimaa.., et al.

Table(6): Explains different types of Zeolites and MG dye removal

\begin{tabular}{|c|c|c|c|c|c|}
\hline \multicolumn{2}{|c|}{ Zeolite Type } & Materials \& Method & Dye & Efficiency & References \\
\hline \multirow{5}{*}{\multicolumn{2}{|c|}{ Natural }} & $\begin{array}{c}\text { Clinoptilolite } \\
\text { With particle size }=0.5-2 \\
\text { mm. }\end{array}$ & MG & $\begin{array}{c}5 \times 10-5 \\
\mathrm{~mol} / \mathrm{g}\end{array}$ & $\begin{array}{l}\text { Wang and } \\
\text { Ariyanto, } \\
2007\end{array}$ \\
\hline & & Mordenite, $0.5-2 \mathrm{~mm}$ & MG & $\begin{array}{c}3.24 \times 10-5 \\
\mathrm{~mol} / \mathrm{g}\end{array}$ & $\begin{array}{c}\text { Ariyanto, } \\
2009\end{array}$ \\
\hline & & $\begin{array}{c}\text { Clinoptilolite }(\sim 68.50 \%)+ \\
\text { montmorillonite and quartz, } \\
\text { size average }=0.4-0.25 \mathrm{~mm}\end{array}$ & MG & $\begin{array}{l}23.94 \\
\mathrm{mg} / \mathrm{g}\end{array}$ & $\begin{array}{l}\text { Han et al., } \\
\quad 2010\end{array}$ \\
\hline & & $\begin{array}{c}\text { Clinoptilolite } 85 \%+\text { gang } \\
\text { minerals, size }<45 \mu \mathrm{m}\end{array}$ & Basic Dye & $>82 \%$ & $\begin{array}{l}\text { Amin } e t \\
\text { al., } 2017\end{array}$ \\
\hline & & $\begin{array}{c}\text { Clinoptilolite, Particle size } \\
=0.25 \mathrm{~mm}\end{array}$ & MG & $98 \mathrm{mg} / \mathrm{g}$ & $\begin{array}{c}\text { Tanyol, } \\
2017 \\
\end{array}$ \\
\hline \multirow{6}{*}{ Synthetic } & $3 \mathrm{~A}$ & $\begin{array}{c}\text { Commercial 3A- Zeolite, } \\
\text { pure chemicals }\end{array}$ & MG & $87.40 \%$ & $\begin{array}{l}\text { Rahmani } \text { et } \\
\text { al., } 2018 \\
\end{array}$ \\
\hline & $4 \mathrm{~A}$ & $\begin{array}{c}\text { Linde Zeolite type A (LTA)- } \\
\text { based on kaolin. } 80 \mathrm{OC} / \\
24 \mathrm{~h}, 5 \mathrm{~mol} / 1 \text { with } 8: 1 \text { of } \\
\mathrm{NaOH} / \text { metakaolin. }\end{array}$ & MG & $55 \mathrm{mg} / \mathrm{g}$ & $\begin{array}{l}\text { Pereira et } \\
\text { al., } 2018\end{array}$ \\
\hline & $\mathrm{Na}+$ & $\begin{array}{c}\text { Calcined bentonite, } 70 \\
0 \mathrm{C} / 2 \mathrm{~h} \\
\text { Product was a mixture of } \\
\text { bentonite }+\mathrm{NaP} \text { Zeolite }\end{array}$ & $\begin{array}{l}\text { Methylene } \\
\text { Blue }\end{array}$ & $\begin{array}{l}36.23 \\
\mathrm{mg} / \mathrm{g}\end{array}$ & $\begin{array}{l}\text { Shaban et } \\
\text { al., } 2018\end{array}$ \\
\hline & $\begin{array}{c}\mathrm{Y}- \\
\text { Zeolite }\end{array}$ & Pure chemicals, $100^{\circ} \mathrm{C} / 12 \mathrm{~h}$, & $\begin{array}{c}\text { Brilliant } \\
\text { Green dye }\end{array}$ & $\begin{array}{c}1461.35 \\
\mathrm{mg} / \mathrm{g}\end{array}$ & $\begin{array}{l}\text { Mittal et } \\
\text { al., } 2020\end{array}$ \\
\hline & $\mathrm{Na}-\mathrm{X}$ & $\begin{array}{l}\text { Commercial type formula, } \\
\text { Na86[(A1O2)86(SiO2)106]. } \\
\text { nH2O). } \\
\text { The crystallite size was } 37.8 \\
\text { nm }\end{array}$ & $\begin{array}{l}\text { Brilliant } \\
\text { Green } \\
\text { (BG) }\end{array}$ & $\begin{array}{l}24.13 \\
\mathrm{mg} / \mathrm{g}\end{array}$ & $\begin{array}{l}\text { Kiwan et } \\
\text { al., } 2021\end{array}$ \\
\hline & $\mathrm{ZA}$ & $\begin{array}{c}\text { From kaolin ( mentioned } \\
\text { previously) }\end{array}$ & MG & $98 \mathrm{mg} / \mathrm{g}$ & This study \\
\hline
\end{tabular}

Where,3A; is 3A-Zeolite, 4A; is Na-A Zeolite, NaP; is Gismondine-

type Zeolite, Y-Zeolite; is Faujasite Na-Y Zeolite, and Na-X; is Faujasite Na-X Zeolite. 
Journal of Environmental Sciences (JES)

Faculty of Graduate Studies and Environmental Research, Ain Shams University

Mahmoud, Al-Shimaa.., et al.

\section{CONCLUSION}

The study investigates low cost technique to remove MG using adsorption based on synthetic ZA. Synthetic ZA that obtained through previous illustrated stages in this study shows well developed crystals with almost uniform particle size distribution. XRD and SEM confirmed suitability of the selected reduced pilot-scale conditions for ZA production. The adsorption results of MG demonstrated that the high removal was found at pH 9 MG adsorption has been fulfilled using pseudo-second-order kinetic model rather than pseudo-first-order with $\mathrm{R}^{2}=0.9853$. The adsorption of MG based on ZA was well fitted by Langmuir isotherms rather than Freundlich isotherm model with correlation coefficient $R^{2}=0.9760$. Furthermore, Dubinin-Radushkevich model has indicated that the adsorption of MG by ZA is a physical process. Thermodynamic calculation has revealed that the adsorption of MG over ZA is spontaneous and the process is endothermic with adsorption capacity $98 \mathrm{mg} / \mathrm{g}$. To conclude, the ZA could be considered as an excellent candidate to be used as coagulant aid and sorbent for the removal of MG in drinking water treatment plant and wastewater and the reduced conditions in terms of less energy consumption, along with using the low-grade Egyptian kaolin in terms of lowering costs were the main economic interest and priority for the current study. Overall, taking green chemistry requirements into account, Zeolites prepared from natural clays (Kaolin) are promising materials for the removal of many environmental pollutants. 


\section{REFERENCES}

Abd-Elrahman, E.: ASynthesis of zeolite nanostructures from waste aluminum cans for efficient removal of malachite green dye from aqueous media. Journal of Molecular Liquids, 253, 72-82. (2018).

Amin, G., Đorđević, D., Konstantinović, S., \& Jordanov, I. (2017): The removal of the textile basic dye from the water solution by using natural zeolite. Advanced Technologies, 6(2), 67-71.

Ariyanto, E. (2009): ADSORPTION MALACHITE GREEN ON NATURAL ZEOLITE. Reaktor, 12(3), 161-165.

Bekkum, V.H., Jansen, J.C., and Flanigen, E.M., (1991): "Zeolites and molecular sieves". (Eds.) Introduction to Zeolite Science and Practice. 58, pp.13-33.

Bonaccorsi, L., \& Proverbio, E. (2008): Influence of process parameters in microwave continuous synthesis of zeolite LTA. Microporous and mesoporous materials, 112(1-3), 481-493.

Bougeard, D., Smirnov, K. S., \& Geidel, E. (2000): Vibrational spectra and structure of kaolinite: A computer simulation study. The Journal of Physical Chemistry B, 104(39), 9210-9217.

Bulut, E., Ozacar, M., Sengil, I.A., (2008): Adsorption of malachite green onto bentonite: equilibrium and kinetic studies and process design. Micropor. Mesopor. Mater. 115, 234-246.

Daneshvar N., M. Ayazloo, A.R. Khataee, M. Pourhassan, Biological decolorization of dye solution containing malachite green by microalgae Cosmarium sp. Bioresour. Technol. 98 (2007) 11761182.

Flanigen Pergamon., E. M., Jansen, J. C., \& van Bekkum, H. (Eds.). (1991): Introduction to zeolite science and practice. Elsevier. 
Farghali, M. A., Abo-Aly, M. M., \& Salaheldin, T. A. (2021): Modified mesoporous zeolite-A/reduced graphene oxide nanocomposite for dual removal of methylene blue and $\mathrm{Pb} 2+$ ions from wastewater. Inorganic Chemistry Communications, 108487.

Garg, V. K., Gupta, R., Yadav, A. B., \& Kumar, R. (2003): Dye removal from aqueous solution by adsorption on treated sawdust. Bioresource technology, 89(2), 121-124.

Gupta, N., Kushwaha, A. K., \& Chattopadhyaya, M. C.: Application of potato (Solanum tuberosum) plant wastes for the removal of methylene blue and malachite green dye from aqueous solution. Arabian Journal of Chemistry, 9, S707-S716, (2016).

Han, R., Wang, Y., Sun, Q., Wang, L., Song, J., He, X., \& Dou, C: Malachite green adsorption onto natural zeolite and reuse by microwave irradiation. Journal of Hazardous Materials, 175(13), 1056-1061, (2010).

Ho, Y.S., McKay, G., (1999): Pseudo-second order model for sorption processes. Process Biochem. 34, 451-465

Hosseinzadeh, H., \& Abdi, K.: Efficient removal of methylene blue using a hybrid organic-inorganic hydrogel nanocomposite adsorbent based on sodium alginate-silicone dioxide. Journal of Inorganic and Organometallic Polymers and Materials, 27(6), 1595-1612, (2017).

Jain, N., Dwivedi, M. K., Agarwal, R., \& Sharma, P. (2015): Removal of malachite green from aqueous solution by zeolite iron oxide magnetic nanocomposite. J. Envi. Sci. Toxicol. Food Technol, 9, 42-50.

Kaith B.S., Jindal R., Sharma R., Synthesis of a Gum rosin alcohol-poly (acrylamide) based adsorbent and its application in removal of malachite green dye from waste water, RSC Adv. 5 (2015): 43092-43104. 
Journal of Environmental Sciences (JES)

Faculty of Graduate Studies and Environmental Research, Ain Shams University

Mahmoud, Al-Shimaa.., et al.

Kiwan, H. A., Mohamed, F. S., El-Ghamaz, N. A., Beshry, N. M., \& ElBindary, A. A: Experimental and electrical studies of Na-X zeolite for the adsorption of different dyes. Journal of Molecular Liquids, 332, 115877, (2021).

Kushwaha, A. K., Gupta, N., \& Chattopadhyaya, M. C: Removal of cationic methylene blue and malachite green dyes from aqueous solution by waste materials of Daucus carota. Journal of Saudi Chemical Society, 18(3), 200-207, (2014).

Lu, T., Xiang, T., Huang, X. L., Li, C., Zhao, W. F., Zhang, Q., \& Zhao, C. S. (2015): Post-crosslinking towards stimuli-responsive sodium alginate beads for the removal of dye and heavy metals. Carbohydrate polymers, 133, 587-595.

Mittal, H., Babu, R., Dabbawala, A. A., Stephen, S., \& Alhassan, S. M. (2020): Zeolite-Y incorporated karaya gum hydrogel composites for highly effective removal of cationic dyes. Colloids and Surfaces A: Physicochemical and Engineering Aspects, 586, 124161 .

Munthali, M. W., Elsheikh, M. A., Johan, E., \& Matsue, N. (2014): Proton adsorption selectivity of zeolites in aqueous media: effect of Si/Al ratio of zeolites. Molecules, 19(12), 20468-20481.

Neag, E., Török, A. I., Tanaselia, C., Aschilean, I., \& Senila, M. (2020): Kinetics and Equilibrium Studies for the Removal of Mn and Fe from Binary Metal Solution Systems Using a Romanian Thermally Activated Natural Zeolite. Water, 12(6), 1614.

Pereira, P. M., Ferreira, B. F., Oliveira, N. P., Nassar, E. J., Ciuffi, K. J., Vicente, M. A. \& De Faria, E. H. (2018): Synthesis of zeolite A from metakaolin and its application in the adsorption of cationic dyes. Applied Sciences, 8(4), 608.

Rahmani, M., Kaykhaii, M., \& Sasani, M. (2018): Application of Taguchi L16 design method for comparative study of ability of $3 \mathrm{~A}$ zeolite in removal of Rhodamine B and Malachite green from 
environmental water samples. Spectrochimica Acta Part A: Molecular and Biomolecular Spectroscopy, 188, 164-169.

Roozeboom, F., Robson, H. E., \& Chan, S. S. (1984): Study on the Mechanism of Crystallization of Zeolites $\mathrm{A}, \mathrm{X}$ and $\mathrm{Y}$. In Zeolites: Science and Technology (pp. 127-147). Springer, Dordrecht.

Shaban, M., Abukhadra, M. R., Shahien, M. G., \& Ibrahim, S. S. (2018): Novel bentonite/zeolite-NaP composite efficiently removes methylene blue and Congo red dyes. Environmental chemistry letters, 16(1), 275-280.

Tanyol, M. (2017): Rapid malachite green removal from aqueous solution by natural zeolite: process optimization by response surface methodology. Desalination and Water Treatment, 65(11), 294303.

Tehrani-Bagha, A. R., Nikkar, H., Mahmoodi, N. M., Markazi, M., \& Menger, F. M. (2011): The sorption of cationic dyes onto kaolin: Kinetic, isotherm and thermodynamic studies. Desalination, 266(1-3), 274-280.

Wang, S., \& Ariyanto, E.: Competitive adsorption of malachite green and $\mathrm{Pb}$ ions on natural zeolite. Journal of Colloid and Interface Science, 314(1), 25-31, (2007).

Wang, M., Xie, R., Chen, Y., Pu, X., Jiang, W., \& Yao, L. (2018): A novel mesoporous zeolite-activated carbon composite as an effective adsorbent for removal of ammonia-nitrogen and methylene blue from aqueous solution. Bioresource technology, 268, 726-732.

Wu, F. C., Tseng, R. L., Huang, S. C., \& Juang, R. S. (2009): Characteristics of pseudo-second-order kinetic model for liquidphase adsorption: a mini-review. Chemical Engineering Journal, 151(1-3), 1-9. 
Yao, Y., Xu, F., Chen, M., Xu, Z., \& Zhu, Z. (2010): Adsorption behavior of methylene blue on carbon nanotubes. Bioresource technology, 101(9), 3040-3046.

Youssef, H., Ibrahim, D., \& Komarneni, S. (2008): Microwave-assisted versus conventional synthesis of zeolite A from metakaolinite. Microporous and Mesoporous Materials, 115(3), 527-534.

Zhuang, Y., Yu, F., Chen, H., Zheng, J., Ma, J., \& Chen, J.: Alginate/graphene double- network nanocomposite hydrogel beads with low-swelling, enhanced mechanical properties, and enhanced adsorption capacity. Journal of Materials Chemistry A, 4(28), 10885-10892, (2016).

\section{إذالال صرغة الملاكيمت الحضراء هن الماء

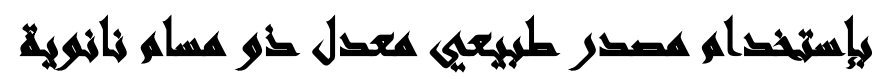

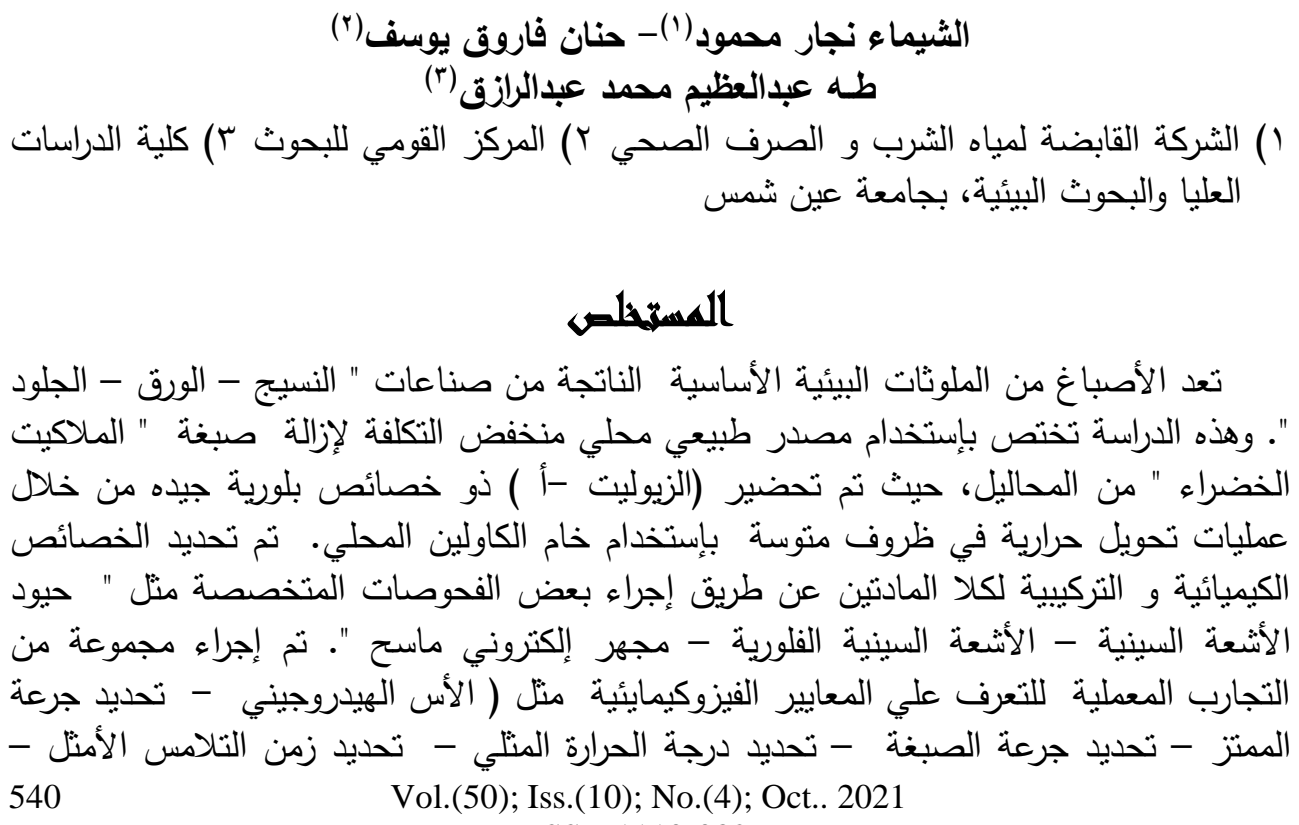

ISSN 1110-0826

Online ISSN 2636-3178 
Journal of Environmental Sciences (JES)

Faculty of Graduate Studies and Environmental Research, Ain Shams University

Mahmoud, Al-Shimaa.., et al.

تحديد تأثنير القوة الأيونية ) وذللك للوصول الي إزلة تامة للصبغة. ايضا تحديد بعض المعايير

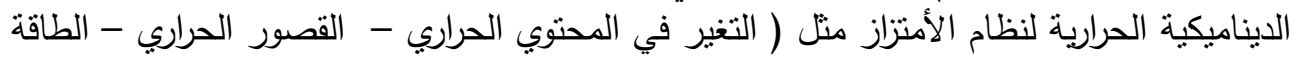

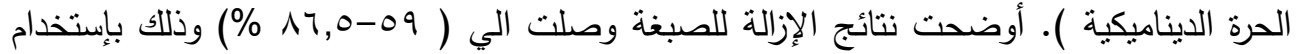

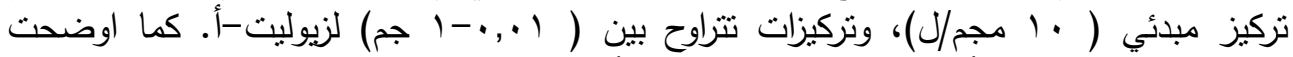

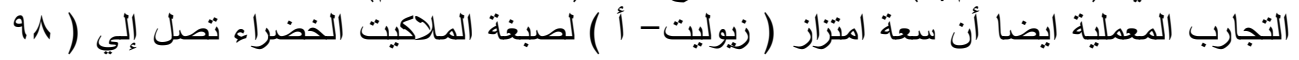

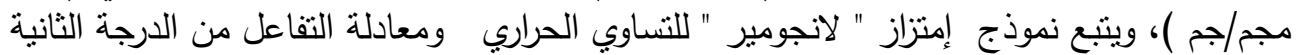
ـ كما اوضحت الدراسات الديناميكية الحرارية لإمتزاز الصبغة علي الإنية الزيوليت (أ) انها تحدث تلقائيا

ويصحبها إمتصاص حرارة.

الكلمات المفتاحية: زيوليت (أ)، مصدر محلي، صبنة النية الملاكيت الخضراء، الإمتزاز و القياسات

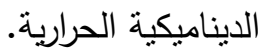

